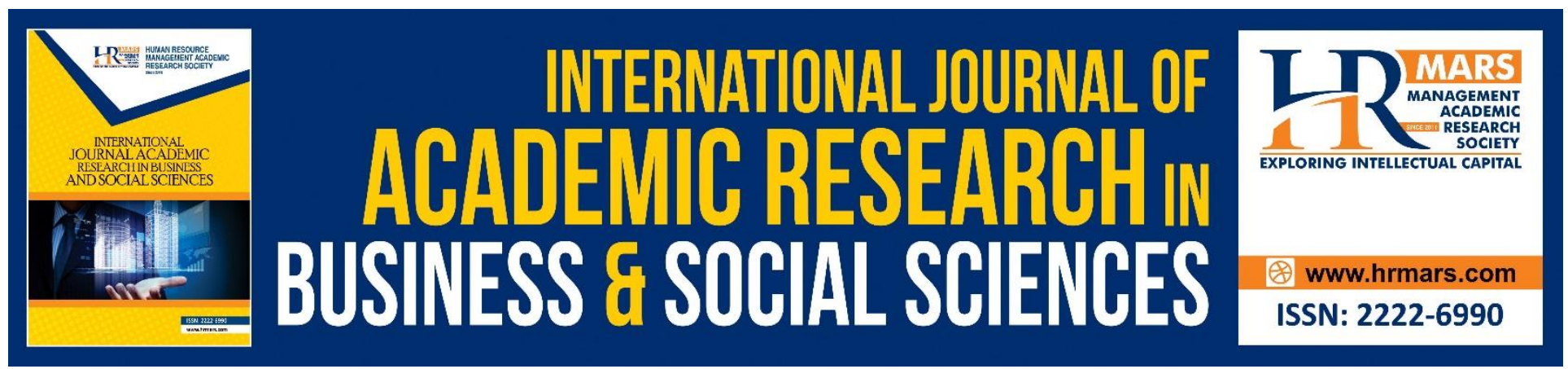

\title{
Gauging the Management's Role in the Implementation of Literature Programme
}

\author{
Siti Salina Mustakim
}

To Link this Article: http://dx.doi.org/10.6007/IJARBSS/v8-i7/4417

DOI: $\quad 10.6007 /$ IJARBSS/v8-i7/4417

Received: 01 June 2018, Revised: 26 June 2018, Accepted: 29 June 2018

Published Online: 13 July 2018

In-Text Citation: (Mustakim, 2018)

To Cite this Article: Mustakim, S. S. (2018). Gauging the Management's Role in the Implementation of Literature Programme. International Journal of Academic Research in Business and Social Sciences, 8(7), 750-762.

Copyright: (C) 2018 The Author(s)

Published by Human Resource Management Academic Research Society (www.hrmars.com)

This article is published under the Creative Commons Attribution (CC BY 4.0) license. Anyone may reproduce, distribute, translate and create derivative works of this article (for both commercial and non-commercial purposes), subject to full attribution to the original publication and authors. The full terms of this license may be seen at: http://creativecommons.org/licences/by/4.0/legalcode

Vol. 8, No. 7, July 2018, Pg. 750 - 762

http://hrmars.com/index.php/pages/detail/IJARBSS

JOURNAL HOMEPAGE

Full Terms \& Conditions of access and use can be found at http://hrmars.com/index.php/pages/detail/publication-ethics 


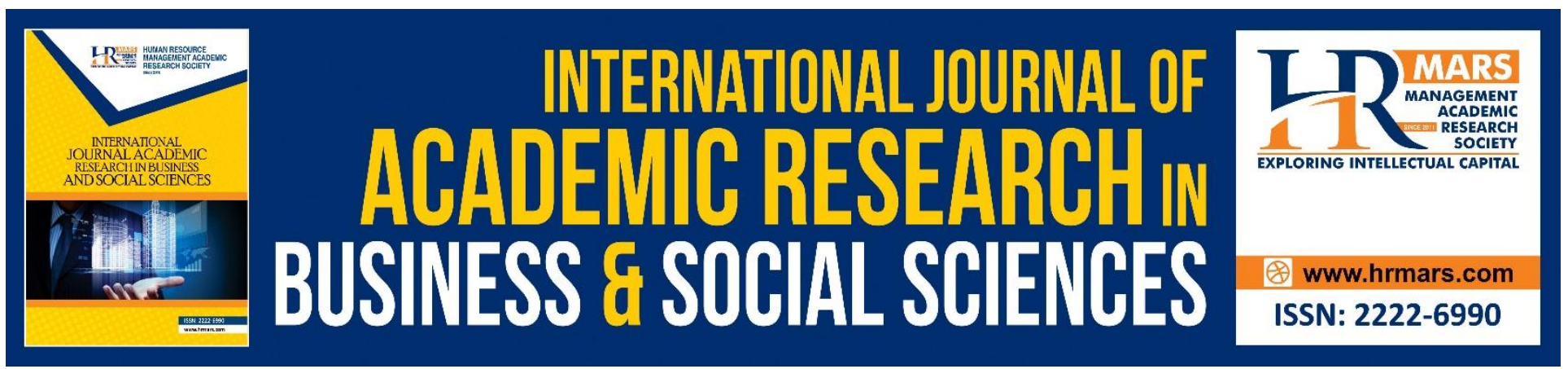

\title{
Gauging the Management's Role in the Implementation of Literature Programme
}

\author{
Siti Salina Mustakim \\ Faculty of Educational Studies, Universiti Putra Malaysia, 43400 UPM Serdang, Selangor, Malaysia
}

\begin{abstract}
The implementation of literature programme in primary schools since 2003, as an intensive reading programme is to inculcate better reading habits that in turn, will contribute to improve English language proficiency. This study determines the management's role in the implementation of literature programme in schools via the provision of five elements; support, resources, training, and time allocation. A cross-sectional survey was conducted to identify the five elements provided by the schools' management. A total number of 234 respondents from 78 schools indicated that majority of respondents were unanimously agreed on the provision of support, resources, training, and time allocation by the schools' management in the implementation of the programme. This study highlights the impact of management's role towards the implementation of literature programme, resources for children's literature, and motivation among teachers towards the implementation of the programme.
\end{abstract}

Keywords: Literature in Education, Contemporary Children's Literature, Evaluation, Children's Literature

\section{Introduction}

Literature in Education (LIE) is aimed at developing the potential of the students in a holistic, balanced and integrated manner encompassing the intellectual, spiritual, emotional and physical aspects in order to create a balanced and harmonious human being with high social standards. Therefore, the primary aim of incorporating literature into English Language syllabus is to improve students' language ability. As stated in the English Language Curriculum Specification, the CCL Program is aimed to help students improve their English through reading simple fiction, to provide a continuum for the literature component introduced in school and to create an enjoyable learning environment. In relation to this, literature is not only meant to address the interpersonal and informational aesthetic value of the learning, but also beyond that where the students learn about people, culture, ethics, behaviours and other social norms. Hence, the implementation of children's literature would help children to expand their imagination and to acquire literacy in their learning.

Pertaining to the implementation of literature programme in primary schools, there is no single best way to determine the effectiveness of a programme implemented in school, neither the best method 
INTERNATIONAL JOURNAL OF ACADEMIC RESEARCH IN BUSINESS AND SOCIAL SCIENCES Vol. 8, No. 7, July 2018, E-ISSN: 2222-6990 @ 2018 HRMARS

to present and describe the adequacy of every provision in a programme implementation. Some issues, such as the provision of support, resources, training, and time allocation, might affect the entire programme implementation and should be discussed for a programme's improvement.

\section{The Provision of Support}

Wide support from administration is crucial in ensuring the success of programmes at school level. Bernam \& McLaughlin (1977) discover in the first major study of innovation involving over 300 US school districts, for instance, that projects which received the active support of the principal are likely to fare well. Hall, Hord, and Griffin (1980) argue that the degree of implementation of the innovation is distinct in different schools because of the actions and concern of the principal. With regards to the implementation of CCL Programme, it was noticeable that there was no attempt at detailed discussion regarding the suitability of the book, the content of the programme and any of the related problems (Shireena Basree, 2007). Head teachers in three schools conducted by Shireena Basree showed broad general support for the programme. Their grasp of what it was expected to entail was often limited. Many of the observation conducted in the previous study drew attention to the poor levels of understanding of the programme expectations.

In Vietnam, the foreign language teaching has been treated differently in a language classroom learning at a different historical stage because Vietnam was under the rule of Chinese for more than 1000 years. English Language Teaching (ELT) in Vietnam was only started and mushroomed in 1986 when the Vietnam government changed their political interest to attract foreign investment. During this period, the provision of support from the government is crucial to ensure the objective is reached. The Ministry of Education and Training (MOET) in Vietnam has underlined the policy in the curriculum to encourage the teaching and learning with the emphasis on English language which occurred just because of the demands for job, communication, and business. Hoa (2007) in her study stated that the policy outlined received widespread support throughout the country from primary schools, parents and pupils. Support in this context includes textbook and other materials for English language teaching and learning. More specific curriculum guidelines are needed, the development of a series of multimedia textbooks, accompanied by audio tapes, videotapes, and a guide for teachers, and instruction of the use of textbooks and teaching materials would be of practical value in effective primary English education. In relation to Hoa's findings, Thai (2005) concluded that the MOET should play a full role in the production, implementation, and communication of policies, not only through issuing policy, but also through meetings with school principals and teachers, and extensive training for all primary English teachers, and direct observation of teaching and learning. Thai's findings as opposed to Hoa's concluded the similarities of requirement from the support elements that is to provide the best resources from the policy maker to the doer of the policy.

Hammersley (2008) in her study conducted on change management and working practices in English primary schools stated that staff felt supported, informed and confident where consultation and communication were valued. Therefore, for primary schools to fully engage in the teaching, it is necessary to rebuild the confidence of teachers as professionals and schools as institutions. She added that if primary schools want to encourage and facilitate enthusiasm and innovation, it is important that they find methods for engaging all staff in opportunities to collaborate and discuss the future of their school in a way that is related to their particular needs and locality. In this context, the importance of teachers support and confident are taken into consideration in order to assist and 
INTERNATIONAL JOURNAL OF ACADEMIC RESEARCH IN BUSINESS AND SOCIAL SCIENCES Vol. 8, No. 7, July 2018, E-ISSN: 2222-6990 @ 2018 HRMARS

motivate teacher to the teaching environment. Without the support provided by the management, and the anticipation of promoting the value of innovation and communication in the institution, the teaching would a tedious and uninteresting.

\section{The Provision of Resources}

A thorough read of the aims and objectives of the CCL Programme, however, leaves no room for doubt that it is a standardized intensive reading programme whereby all schools across all states are required to use a designated set of three storybooks. The Ministry Official provided confirmation that it is compulsory for all the students to complete the three titles specified by the Ministry first; it is only at this point that teachers may provide other forms of extended reading, especially for the more proficient classes. However, a study conducted by Shireena Basree (2007) states that schools received 'a lot of books' when actually; at the most, they received only a total of one hundred and twenty books, forty books per title. In overcoming the shortage of book provided to schools, teachers were able to use stories of any kinds in the classroom instruction. According to Maley (2001) cited by Saraceni (2003), the text may also be used as an example to certain types of pattern and structure. Using any kind of stories could lead to the same objective of learning.

In Singapore, Jones (2012) in her study about reading in the English medium primary school in Singapore argued that what pupils are expected to read, and how they are expected to read makes the reading task in upper primary very complex. She analysed three texts from primary three textbooks in English, Maths, and Science. It shows how reading in each subject requires children to draw different knowledge resources, similar to study by Anderson (1994). Therefore, in order to reach these knowledge resources, children need to develop familiarity with the text types common to the different school disciplines. Jones suggested two reading strategies to increase knowledge and understanding in teaching reading. The first suggestion is to increase knowledge of how children are reading through talking with them about the reading process and helping them to develop a metalanguage, the second is to increase knowledge of discipline specific genres and texts through analysing them. She stated that engaging in these two processes would enable the understanding discipline of specific genres and flexibility to teaching reading in English and other subjects.

Smith, Fotinatos, Duffy, Burke \& Jenene (2012) in their study about The Provision of Sexual Health Education (PHSE) in Australia: Primary School Teachers' Perspectives in Rural Victoria stated about the importance of the provision of resources in their findings. It was stated that enormous financial and curriculum resources have been committed to PHSE delivery nationally and internationally to achieve the desired outcome of developing positive health behaviours to support young adults in reading their potential. While in Vietnam, pertaining to curriculum planning for primary English education, most of the cities and provinces declare that they have adequate resources (teachers, facilities, parents' needs and children's interests) to introduce English language in their programmes. Hoa (2007) argued that the curriculum in Vietnam is more successful if the instructional materials provided are in readiness for the implementation of the policies.

\section{The Provision of Training}

Cascade training was provided by the MOE in the early implementation of CCL Programme. In the year 2008, a group of 24 ESL teachers from three states in Malaysia were sent to a one-month projectbased course in RELC Singapore on how to teach English through literature (Sarala, 2012). These 
INTERNATIONAL JOURNAL OF ACADEMIC RESEARCH IN BUSINESS AND SOCIAL SCIENCES Vol. 8, No. 7, July 2018, E-ISSN: 2222-6990 @ 2018 HRMARS

teachers were then required to conduct the same course to other teachers in their particular states, districts and schools. Nevertheless, the course held was inadequate and insufficient and sometimes held even just for one day. The cascade training is important for the teachers to adapt with the teaching using modules provided by the MOE and at the same time, to ensure the classroom instruction fits with the needs and expectation of the time scheduled in the timetable allocated by the administrator. Shireena Basree (2007) states that there are various problems with the cascade model of training used to prepare teachers responsible for the implementation of CCL. The shortage of specialist English teachers available for training, the in-house training is not common in Malaysian schools, the heavy workload placed upon the teachers, and the very limited nature of monitoring the programme and assistance beyond state level training are just some of them.

Price and Willet (2006) in their study about primary teachers' perceptions of the impact of initial teacher training upon primary schools indicated that the involvement of Initial Teacher Training (ITT) was valued by the primary head teachers, mentors and teacher tutors in their schools. It was found that a wide range of benefits was recognized which include (1) the encouragement of reflective

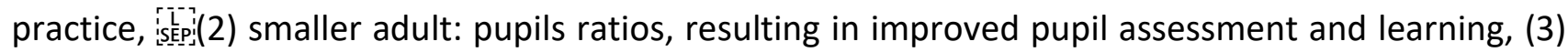
rejuvenation, including the introduction of new ideas, resources and skills within the curriculum and different approaches to teaching and learning, (4) the development of a wide range of mentoring skills which are transferable to other contexts, and (5) a range of impacts on the wider school including recruitment. They added that a formal training provided by university on teachers' training increased professional development. The training provided could enhance a teacher's application for promotion.

Shaw (1992) suggests that ITT involvement may also raise pupil's achievement, while Child and Merrill's study (2003) provides evidence that ITT was powerful in raising standards. The advantages of ITT were indicated that teachers would be teaching better, which would have a positive effect on achievement.

In Vietnam, teachers' training is indispensable in the process of curriculum planning and development. Training in language teaching methodology specifically for teachers is necessary. It is essential for the MOET to provide more English classes with English native speakers as a part of teachers' training.

Hallam, Burnard, Robertson, Saleh, Davies, Rogers, Kokatsaki, \& Dimitra (2009) in their study about Trainee Primary-School Teachers' Perceptions of their Effectiveness in Teaching Music indicated that many primary school teachers entering the teaching profession in England feel that the amount of training they have received in relation to teaching music has been inadequate although the quality of that training is high. This finding is related to collaborative work with special teachers as an initiative from other teachers to develop their skills of teaching due to the inadequacy of training provided. Beauchampt (1997) argued that teachers favour this system, and exist evidence that this system can be effective (Gamble, 1988). The ITT provided has been found to be the strongest determinant of the level of music education (Temmerman, 1997), and affects teachers' ability to teach music adequately (Darling- Hammond, 2001). In this context, the development of teachers' confidence functions as an important determinant of the extent to which music is taught in the classroom (Bresler 1993; Gifford 1993; Mills 1989; Russell-Bowie 1993, 2002). 
INTERNATIONAL JOURNAL OF ACADEMIC RESEARCH IN BUSINESS AND SOCIAL SCIENCES Vol. 8, No. 7, July 2018, E-ISSN: 2222-6990 @ 2018 HRMARS

Heywood (2005) in his study on Primary Trainee Teacher's Learning and Teaching about Light: Some Pedagogic Implications for Initial Teacher Training (ITT) indicated that the appropriation of training provided for teachers is essential since they are required to know about light phenomena in the teaching. Teachers have low understanding of the rationale that underpins the basic idea permanently in the prescribed curriculum. Therefore, the requirement of training to non-specialist where tutorial support is limited is categorized as a matter for conjecture.

\section{The Provision of Time Allocation}

Time allocated for the teaching and learning of CCL Programme is one period per week (Malaysia Ministry of Education. 2006). Teachers and students are required to teach and to learn three books in a year, which consists of stories and poems. At any one time, students will have one book to read for every three months. The CDD has allocated "books on rotation basis" to be taught by teachers and learnt by students in the classroom. They are shown in Table 1:

Table 1: Books on Rotation Basis in CCL Programme

\begin{tabular}{|l|l|l|l|}
\hline & Year 5A & Year 5B & Year 5C \\
\hline January - April & Title 1 & Title 2 & Title 3 \\
\hline May - July & Title 3 & Title 1 & Title 2 \\
\hline August - September & Title 2 & Title 3 & Title 1 \\
\hline
\end{tabular}

With the implementation of one period per week, teachers are required to fulfill the requirement of the aims which are to (1) improve pupils' English reading, (2) provide a continuum for the literature component introduced in secondary school, and (3) create an enjoyable learning environment. They are also required to fulfill the objectives to (1) instill and inculcate the reading habit among pupils, (2) enrich pupils' vocabulary and language content, (3) enhance pupils' thinking skills, (4) promote cultural understanding in the Malaysian context, (5) improve English language proficiency, and (6) provide lively, enjoyable and high-interest readings (Malaysia Ministry of Education. 2006).

\section{Methodology}

The main purpose of this study was to determine the management's role in the implementation of literature programme in primary schools. A cross-sectional survey was employed as an effort to determine teachers' agreement towards the provision of support, resources, training, and time allocation provided by the school management in the implementation of literature Programme. The structured questionnaire's main orientation is to identify and assess current system capabilities, to search out and critically examine potentially relevant approaches, to recommend alternative programme strategies, and identify platform of issues and concern from the programme implemented.

The state of Selangor was selected for the study due to its highest number of candidate in 2013, as stated in the Malaysia Educational Statistics 2014, MOE. Respondents for survey questionnaire were stratified random sampling selected from 191 National Primary schools. The selected schools were 
INTERNATIONAL JOURNAL OF ACADEMIC RESEARCH IN BUSINESS AND SOCIAL SCIENCES Vol. 8, No. 7, July 2018, E-ISSN: 2222-6990 @ 2018 HRMARS

divided into five zones. There were 32 primary schools in North zone, 35 primary schools in the West zone, 59 primary schools in Middle zone, 46 primary schools in the East zone and 19 primary schools in the South zones. The questionnaires were administered to 78 National Primary schools from five districts. In order to examine the breadth, size and depth, and quality of the implementation of $\mathrm{CCL}$ Programme, the questionnaires were administered to teachers who teach CCL Programme for Years 4,5 , and 6 in Selangor primary schools. This is due to the reason of the implementation of the programme itself where it is simply implemented for Years 4, 5 and 6. According to EMIS Data records (MOE, 2011), the population of all ESL teachers who teach Years 4, 5, and 6 in Selangor primary schools from the five zones (National Schools) are 573. From this population, the samples were selected based on Krejcie \& Morgan's (1970) formula. According to Krejcie \& Morgan (1970) in determining the sample size for research activities, the appropriate sample size of 573 populations is 234. Therefore, 234 teachers were sufficient as the sample size for the study.

\section{Findings and Discussion}

Findings of the study is presented in accordance to feedback from respondents on support, resources, training, and time allocation provided by the schools' management in the implementation of literature programme.

\section{Demographic Profile of the Respondents}

Malay was the majority respondent in the study (82.5\%). The number of female respondents is $73 \%$ and male $27 \%$. Out of 234 respondents, $17.5 \%$ were 50 years and above, $33.3 \%$ were in age group of 40 to 49 years old. The other $29.5 \%$ and $19.7 \%$ were in age group of below 39 years old. Teaching experience of the respondents showed that the highest teaching experience were teachers in the age group from 20 to 29 years old (32.5\%) and the lowest teaching experience were teachers in age group 30 years and above (12.0\%) and teachers in age group below four years (12,0\%). Only $9.4 \%$ of the teachers have 30 years experience of teaching English. 25.6\% belonged to age group of 10 to 19 years old teaching experience. The other $19.2 \%$ and $12 \%$ belonged to age group of below 9 years of teaching experience. Education attainments of the respondents were categorized according to Malaysia Certificate of Examination (MCE), Higher Certificate Secondary of Examination (HSCE), Diploma, Bachelor, Bachelor of Education, and Master level. Results showed that Bachelor had the highest percentage of respondents (30.3\%) while Master had the lowest percentage of respondents with only 3.85\%. 30.3\% of them are Diploma in Education holders, and $12 \%$ of them are Teaching Certificate holders. Teachers' specialization in Malaysian Education of Institution (MEI) or University showed $68.8 \%$ majoring at English as a Second Language (ESL) teaching and the $31.2 \%$ were at various field of teaching. With regard to levels of courses attended in the implementation of CCL Programme, $17.5 \%$ of the respondents attended courses only at district level, $5 \%$ at state level, and below than $1 \%$ at Ministry of Education level. While the other $77.4 \%$ never attended any courses related to $\mathrm{CCL}$ Programme.

\section{Respondents' Feedback on Support}

Result in Table 2 provides information related to provision of support by the schools' management via the role and assistance of administrators. Overall, the average mean score is 2.77 and standard deviation is .579 for the provision of support. Mean score indicated that in general, teachers agreed on the provision of support provided by the school management. Specifically, item 11 indicated that majority of respondents agreed (73.5\%; mean 2.89; SD .58), that the administrators paid attention 
INTERNATIONAL JOURNAL OF ACADEMIC RESEARCH IN BUSINESS AND SOCIAL SCIENCES Vol. 8, No. 7, July 2018, E-ISSN: 2222-6990 @ 2018 HRMARS

and sensitive to provide the necessary equipment and facilities in the implementation of the programme. Item 16 too, indicated that majority of the respondents agreed (64.5\%; mean 2.68; SD .54), the administrators observe and supervise their teaching in the implementation of the programme. Findings of item 16 goes in line with item 11 where (72.2\%; mean 2.85; SD .58), when the respondents agree that their administrators understand the objectives and goal of $\mathrm{CCL}$ Programme implementation in school. Respondents too agreed (75.2\%; mean 2.91; SD 50) that they are given opportunity to try out new ideas in teaching, provide guidance and assistance in carrying out the implementation of CCL Programme (56.8\%; mean 2.66, SD .64).

Table 2: Feedback on the Provision of Support ( $\mathrm{N}: 234)$

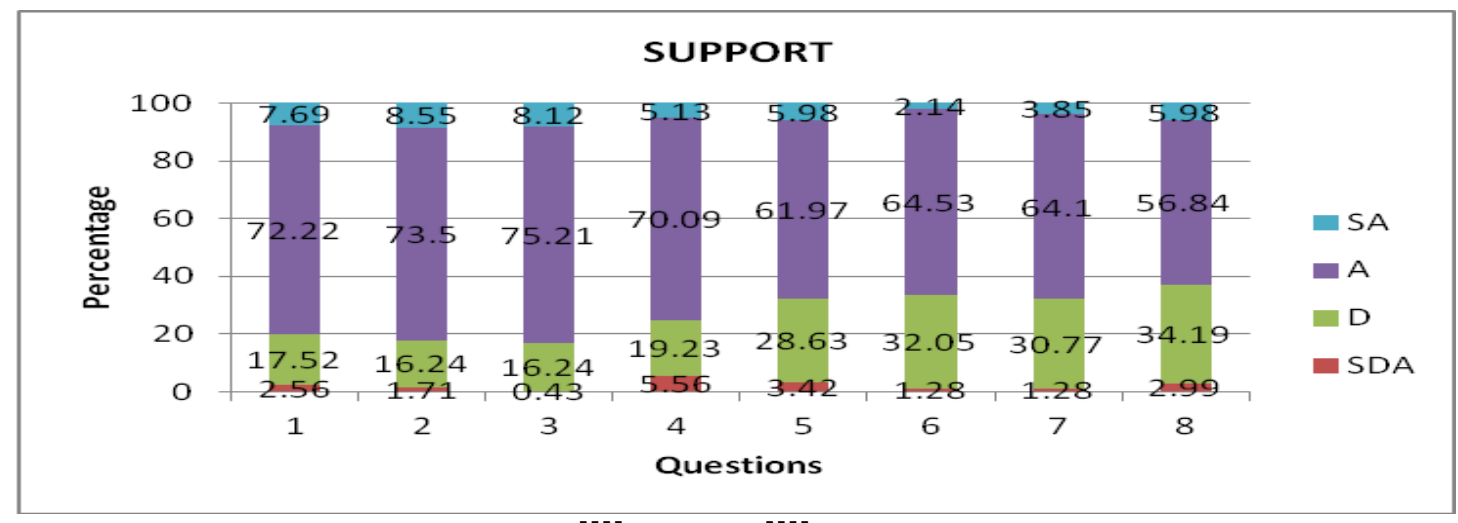

SD: Strongly Disagree D: Disagree

\section{Respondents' Feedback on Resources}

Result in Table 3 is related to respondents' feedback on resources provided by the school management via the provision of language room, teaching aids, and financial support. It was found that the administrators allowed students to carry out activities in the language room (61.1\%; mean 2.73; SD .62), and permits the English language panel to be responsible to manage the expenses for the CCL Programme (71.8\%; mean 2.79; SD .55). Teachers are using the CCL Programme module as a guide to teach CCL Programme (64.1\%; mean 2.79, SD .59) which closely related to item 4, which indicated that $31.2 \%$ (mean 2.72; SD .58) of the respondents disagree that the administrator provides opportunity for teacher to be involved with the expenditure planning of CCL Programme, and the opportunity to be involved in the purchase of goods pertaining to the implementation of the programme.

Table 3: Feedback on the Provision of Resources (N: 234) 
INTERNATIONAL JOURNAL OF ACADEMIC RESEARCH IN BUSINESS AND SOCIAL SCIENCES Vol. 8, No. 7, July 2018, E-ISSN: 2222-6990 @ 2018 HRMARS

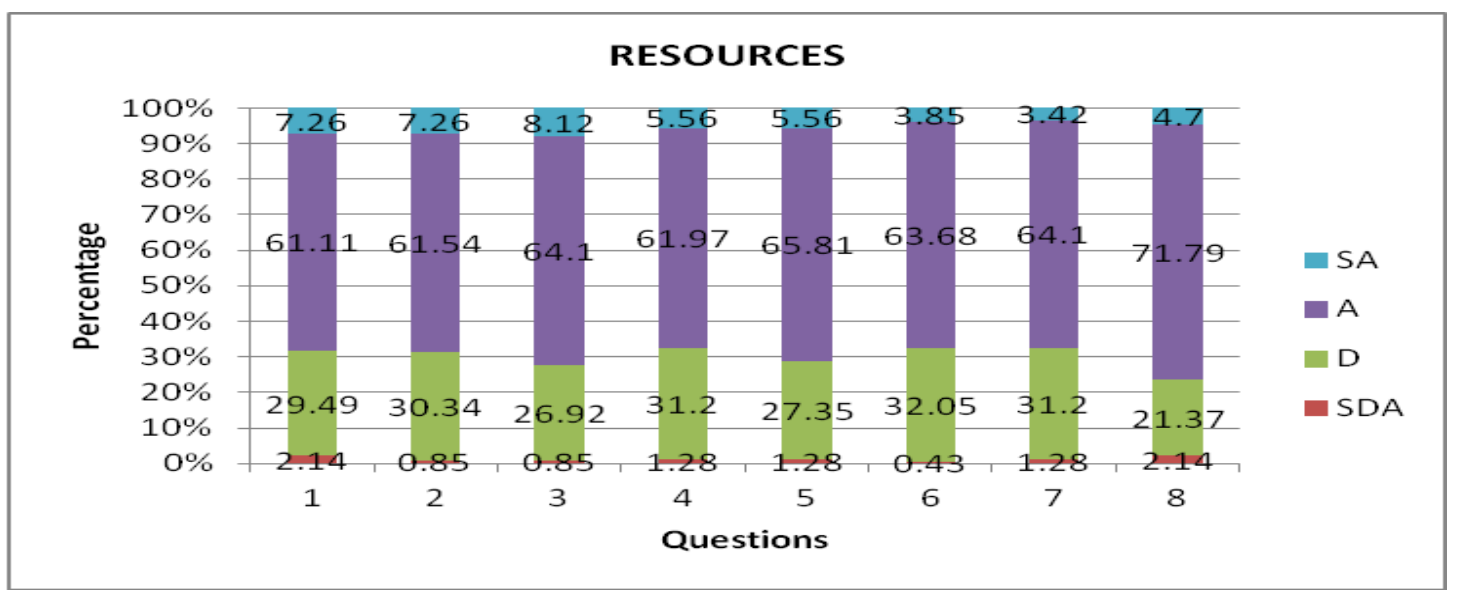

SD: Strongly Disagree D: Disagree

\section{Respondents' Feedback on Training}

Result in Table 4 provides information related to respondents' feedback on training provided by the state / district / school department that the respondents have attended. It was found that $70.5 \%$ (mean 2.71; SD .60) of the respondents agree that the training and courses provided assists them in the teaching of CCL Programme. 61.5\% (mean 2.60; SD .59) agree that the time for training provided is sufficient as a preparation to teach literature in their schools. However, respondents disagreed in item 27 (3.8\%; mean 2.6; SD .61) that the training provided is sufficient as a preparation to teach $\mathrm{CCL}$ Programme in schools. Respondents agreed that the instructor for the training is a capable and knowledgeable person (64.8\%; mean 2.71; SD .58), handouts and other related materials provided during the training are sufficient and adequate (64.5\%; mean 2.71; SD .60), they received full benefit each of the programme they have attended (63.7\%; mean 2.67; SD .61), they always attended training and course provided by the state / district / schools' department (62\%; mean 2.71; SD .64), and they feel confident to teach after attending the training and courses provided (62.8\%; mean 2.71; SD .60).

Table 4: Feedback on the Provision of Training (N: 234)

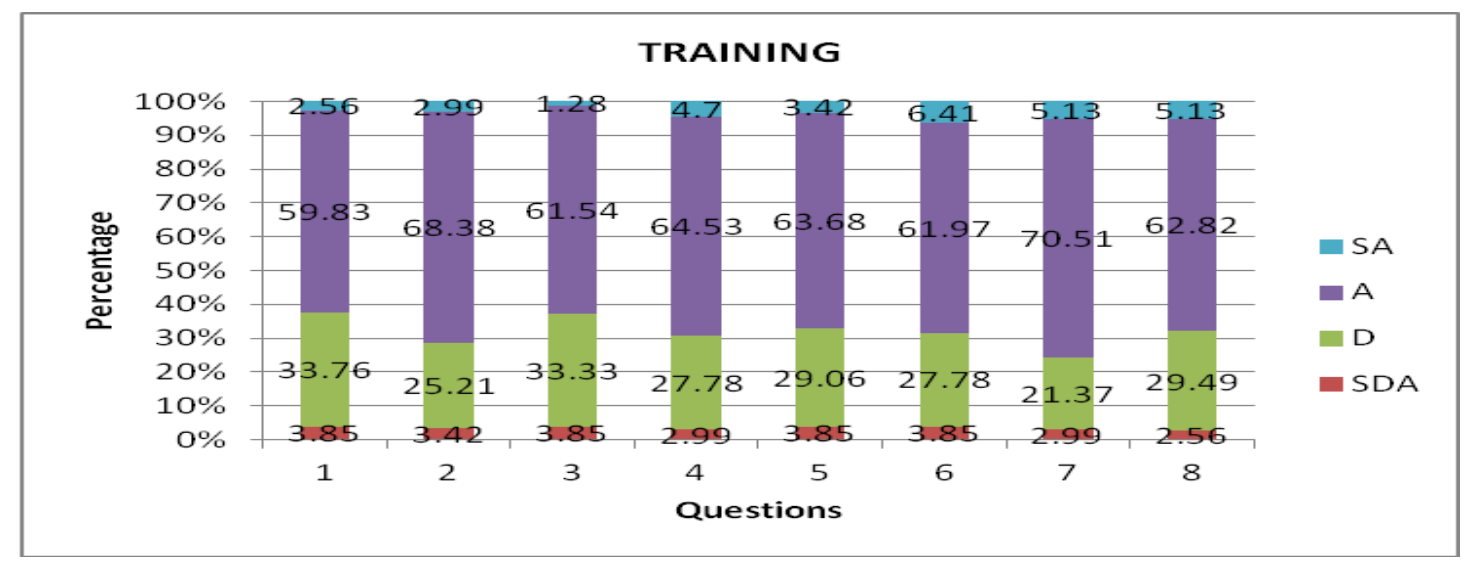

SD: Strongly Disagree D: Disagree

\section{Respondents' Feedback on Time Allocation}

Result in Table 5 provides result related to respondents' feedback on time allocation in the 
INTERNATIONAL JOURNAL OF ACADEMIC RESEARCH IN BUSINESS AND SOCIAL SCIENCES Vol. 8, No. 7, July 2018, E-ISSN: 2222-6990 @ 2018 HRMARS

implementation of CCL Programme. Only 52.6\% (mean 2.56; SD .59) of the respondents agreed that the allocation of time is sufficient for the teaching and learning of CCL Programme. It was found in Item 36 (58.5\%; mean 2.63; SD .60) that the combination of teaching schedule is appropriate for the teaching and learning of the programme, Item 37 (60.3\%; mean 2.74; SD .59) that the allocation of time gives consideration to the views of English teachers, Item 38 (66.2\%; mean 2.74; SD .59) the implementation of the programme gives consideration to the views of English teachers, Item 39 (60.3\%; mean 2.67; SD .61) shows that the allocation of time ensures that there is no overlap with any other use of the Language room when the CCL Programme is taught.

Table 5: Feedback on the Provision of Time Allocation (N: 234)

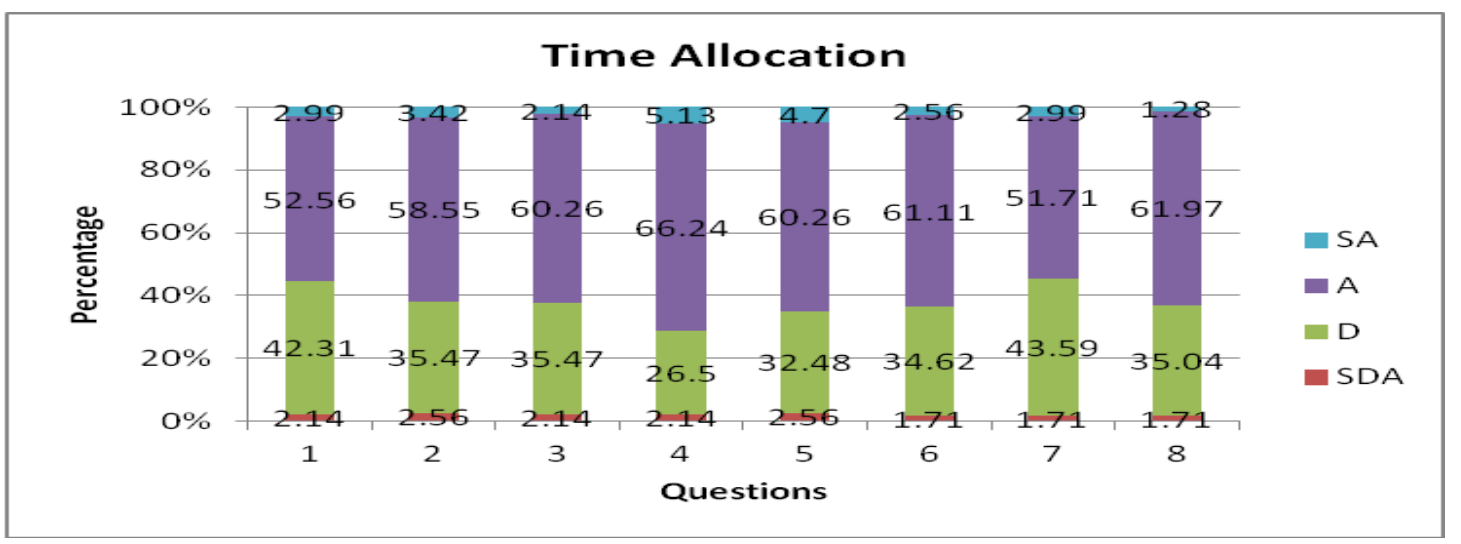

SD: Strongly Disagree D: Disagree

\section{Conclusion}

Findings concluded that most of the respondents unanimously Agreed with the provision of support, resources, training, and time allocation in the implementation of CCL Programme. Therefore, out of 234 respondents from 78 primary schools in the state of Selangor, cumulative from findings in the Likert Scale of (1) support were 67.3\% Agreed (mean 2.77; SD .58) on the role and assistance given by the administrators, (2) resources were 64.3\% Agreed (mean 2.75; SD .58) on the accessibility of language room, teaching aids, and financial support, (3) training were 64.2\% Agreed (mean 2.69; SD $.60)$ on capability of the instructor provided, sufficient training time and availability handouts during training, received full benefits of the training, and confidence to teach after attending the training, and (4) time allocation were 59.0\% Agreed (mean 2.63; SD .58) on combination of the teaching schedule, consideration for teachers to adjust the teaching of $\mathrm{CCL}$, sufficient time to teach two books in a year, and the priority given for timetable development to teach CCL. The scope and quality of support, resources, training, and time allocation in the implementation of CCL Programme in Selangor primary school has been verified by these data which majority of teachers agreed with the provision they received by the school management.

In line with the implementation of CCL Programme, the existence of 'Nilam' Programme by the school library is seen beneficial for teachers to enhance students' reading abilities. With extra short story books as provisions in the library, the teachers' guidance and assistance during this programme, students are able to receive prompt feedback and a 'one-to-one' basis of learning in comprehending 
INTERNATIONAL JOURNAL OF ACADEMIC RESEARCH IN BUSINESS AND SOCIAL SCIENCES Vol. 8, No. 7, July 2018, E-ISSN: 2222-6990 @ 2018 HRMARS

the literary text they read. In this circumstance, several considerations were taken into account which are: (1) the conducive environment in the library, (2) the focus of attention to enhance students reading and comprehension of literary text to help them for English language proficiency due to Standard Examination, (3) the 'one-to-one' basis of learning with teachers, (4) less tasks in Pre, While, and Post-Reading Activities, and (5) excluded the portfolio development.

Nevertheless, teachers' development in the teaching of $\mathrm{CCL}$ is considered moderate. Teachers anticipated in the "Nilam" Programme that assisting students to enhance their English language proficiency, and at the same time cultivated the teaching of other component such as pronunciation, vocabulary enrichment, and translating the text into the first language. To some extent, there were cases where the module and short story books were not utilized in the teaching. The utilization of short text related to literature teaching was employed in the teaching. Analysis related to some components of character, moral values, and setting were taught by teachers, as well as the teaching of English language grammar and others.

The existence of Reading Corner, Reading Corridor, Reading Mural, and Notice Board for CCL Programme implementation encouraged students to move themselves to these area for further information about literature learning. The attractiveness and conveniences of the places aroused students to yearn for English literacy. These places becomes the platform for discussion, reading, and extra activities for learning during their free time particularly during recess, transit from one session to another, and personal discussion with teacher.

Another motivation for learning derived from the implementation of "Nilam" Programme by the school library. With the conducive environment provided by the library as opposed to Reading Corner, Reading Corridor, Reading Mural, and Notice Board in the school compound, students inculcated reading, discussion, and 'one-to- one' basis learning with teachers. They received extra attention from teachers due to no activities involved in the "Nilam" Programme. The task is less effective due to the focus of "Nilam" Programme is only for reading comprehension.

Overall, this study highlights the status of English literature programme's implementation in primary schools. From the issues highlighted, this is reflected in the fact that English teachers show great interest in the approaches of teaching literature, but after several lacking founds during the implementation of the programme, they continue teaching in the old methods, by focusing on the Standard Examination, and the technical teaching of English language (reading, writing, listening, speaking). The only sure aids available are the literature textbooks and the CCL Module provided by the MOE, and sometimes, the Pre, While, and Post Teaching in the classroom was not happened. In this circumstances, the management's role is crucial to ensure the provision of support, resources, training, and time allocation in order to implement the programme effectively.

\section{References}

Anderson, R. C. (1994). Role of the reader's schema in comprehension, learning and memory. In R. B. Ruddell, M. R. Ruddell \& H. Singer (Eds.), Theoretical models and process of reading $\left(4^{\text {th }}\right.$ ed) (pp. 469-482), Newark, Delaware: International Reading Association.

Beauchamp, G. (1997). Initial training 'INSET' confident teachers. A formula for success? British Journal of Music Education, 14(1), 69- 85.

Bernam, P. \& McLaughlin, M. W. (1977). Factors affecting implementation and continuation. Vol. 
INTERNATIONAL JOURNAL OF ACADEMIC RESEARCH IN BUSINESS AND SOCIAL SCIENCES

Vol. 8, No. 7, July 2018, E-ISSN: 2222-6990 @ 2018 HRMARS

7 of federal programs supporting educational change (R-1589/7 HEW). Santa Monica, CA: Rand. (ERIC Document Re-production Service No. ED 140 432).

Bresler, L. (1993). Music in a double bind: Instruction by non-specialists in elementary schools, Bulletin of the Council for Research in Music Education 115(1).

Basree, S., (2007). The Implementation of the Contemporary Children's Literature Program in Malaysian Primary Schools. PhD Thesis, University of Reading, UK.

Child, A. J. \& Merrill, S. J. (2003) Professional mentors' perceptions of the contribution of School. HEl partnerships to professional development and school improvement. Journal of Inservice Education, 29(2), 315-324.

Darling-Hammond, L. (2000). How teacher education matters. Journal of Teacher Education, 51(3), 166-173.

Gamble, S. (1988). The elementary classroom teacher: An ally for music education. Music Educators Journal, 75(1), 25-8.

Gifford, E. (1993). The musical training of primary teachers: Old problems, new insights and possible solutions. British Journal of Music Education 10, (33-46).

Hall, G. E. Hord, S. \& Griffin, T. (1980). Implementing Change (Third Edition). New York: Routledge-Falmer.

Hallam, S., Burnard, P., Robertson, A., Saleh, C., Davies, V., Rogers, L., \& Kokatsaki, D. (2009). Trainee primary-school teachers' perception of their effectiveness in teaching music. Journal of Music Education Research, 11(2), 221 - 240.

Hammersley-Fletcher, L. (2008). The impact of Workforce Remodeling on change management and working practices in English primary schools. Journal of School Leadership \& Management, 28(5), 489 - 503.

Heywood, D. (2005). Primary trainee teachers' learning and teaching about light: some pedagogic implications for initial teacher training. International Journal of Science Education, 27(12), 1447- 1475.

Hoa, N. \& Tuan, N. (2007). Teaching English in Primary Schools in Vietnam: An Overview. Journal of Current Issues in Language Planning, 8(2), 162-173.

Jones, S (2012). Decontextualizing reading, rethinking teaching: Reading in the English medium primary school in Singapore. Journal of Education 3-13, 40(3), 243-258.

Krejcie, R. V. \& Morgan, D. W. (1970). Determining Sample Size for Research Activities. Educational and Psychological Measurement, 38, 607-610.

Malaysia Ministry of Education. (2011). EMIS Data (12). Kuala Lumpur.

Maley, A. \& Duff, A. (1990). Literature. Oxford: Oxford University Press.

Mills, J. 1989. The generalist primary teacher of music: A problem of confidence. British Journal of Music Education 6, (2), 125-138.

Price, A. \& Willet, J., (2006). Primary teachers' perceptions of the impact of initial teacher training upon primary schools. Journal of In-Service Education, 32(1), 33 - 45.

Russell-Bowie, D. (1993).Where is music education in our primary schools? Research Studies in Music Education 1: 40-51.

Russell-Bowie, D. 2002. Where in the world are we? Australian Journal of Music Education (1), 33-44.

Saraceni, M. (2003). Literature in the EFL Classroom: Roses or thorns? In G. Subramanian (Ed.), Teaching literature in ESL/EFL contexts, pp. 13-26. Petaling Jaya: Sasbadi-Melta ELT Series. 
INTERNATIONAL JOURNAL OF ACADEMIC RESEARCH IN BUSINESS AND SOCIAL SCIENCES

Vol. 8, No. 7, July 2018, E-ISSN: 2222-6990 @ 2018 HRMARS

Sarala A/P Subramanyam. (2012). English Language Teaching. The Malaysia International Conference on English Language Teaching MICELT 2012, pp. 110-114. UPM, Serdang. Malaysia: Department of Language \& Humanities Education.

Shaw, R. (1992) Can mentoring raise achievement in schools? In Wilkin, M. (Ed) Mentoring in Schools, London, Kogan Page, pp.82-95.

Smith, A., Fotinatos, N., Duffy, B., Burke, B. \& Jenene (2013). The provision of sexual health education in Australia: primary school teachers' perspectives in rural Victoria. Journal of Sex Education, 13(3), 247-262.

Temmerman, N. 1997. An investigation of undergraduate music education curriculum content in primary teacher education programmes in Australia. International Journal of Music Education 30, 26-34.

Thai, T.Q. (2005). The current situation of primary ELT in Vietnam. Paper presented at the Teaching English Language at Primary Level Conference, Hanoi, Vietnam. 